

\title{
Corporate governance mechanism and the moderating effect of independency on the integrity of financial reporting
}

\begin{abstract}
The purpose of this study is to examine the moderating role of independency on the relationship between corporate governance mechanism and institutional ownership, managerial ownership, independent commissioners, audit committee and the quality of public accounting firm in the integrity of financial statements. This study used a sample of companies listed on the Indonesian Stock Exchange in 2014. A total of 138 companies were examined. Moderated Regression Analysis (MRA) was used to test the hypotheses. Results show that independency has a full moderating role on the relationship between institutional ownership, independent commissioners and quality of public accounting firm in the integrity of financial statements. Independency has no moderating role on the relationship between managerial ownership and audit committee in the integrity of financial statements.
\end{abstract}

Keywords: independency, corporate governance mechanism, quality, integrity.

JEL Classification: G34, M41, M48.

\section{Introduction}

To realize the integrity of financial statements, each company must implement corporate governance practices. The Indonesian Minister for State Owned Enterprises Number Per-01/MBU/2011 defines corporate governance practices as "the process and structure used by the state to improve the success of business and corporate accountability in order to create shareholder value in the long term by taking into account the interests of other stakeholders, based on the laws and ethical values". Thus, corporate governance means a set of rules that is used as a reference by management of the company to manage the company as good, true, and full of integrity, especially in the presentation of financial statements. According to the Report on the Observance of Standards and Codes (The World Bank, 2005, 2), corporate governance refers to the structures and processes of the direction and control of companies. Corporate governance concerns with the relationships among the management, board of directors, controlling shareholders, minority shareholders and other stakeholders. The integrity of the financial statements is the extent to which the financial statements are presented showing the correct information and honesty (Mayangsari, 2003).

According to Kieso et al. (2007), financial reports are said to be having integrity when meet the quality reliability and in accordance with the generally acceptable accounting principles (GAAP). Financial reports are considered to be reliable if they have the following characteristics: power test (verifiability), the accuracy of the representation (representational

\footnotetext{
(C) Enni Savitri, 2016.

Enni Savitri, Ph.D. in Managerial Finance from Universitas Brawijaya, Indonesia; Senior Lecturer, Department of Accounting Faculty of Economics Universitas Riau, Indonesia
}

faithfulness), and neutrality. Information is regarded as having the ability to influence the decisions of the readers of financial statements to help them to make decisions.

There seem to be many companies in Indonesia that are still unable to present financial information with high integrity. Many cases of accounting manipulations (earnings management) were identified. Earnings management occurs when the information presented is biased and not appropriate for some of the users of financial statements as a result of management of accounting information. The results of the financial reporting investigation by the Indonesian Supreme Audit Agency on the first half of 2014 on the central government, local governments, other agencies, and state owned enterprises and other forms of corporations show that there were weaknesses in the system of internal control. In this case, there were as many as 5,948 cases and the findings of non-compliance with the provisions of the legislation as much as 7,173 cases with losses amounting to IDR10.93 trillion (bpk.go.id).

A large number of evidence on low integrity suggest that many companies do not implement corporate governance and good internal control. Basically when the corporate governance fails, it will lead the company to reporting failure whereby most of them manipulated their financial statement. The governance failure occuring at national or organization level has called upon the pressure to report about reviews of the companies performance reports. In order to show that the company's performance is in line with the expectation, managers have the incentive to produce a false accounting, earnings management and other aggressive reportings but there seems to be no transparency, accountability, and integrity. (Norwani et al., 2011). 
People really need independency on corporate governance and an auditor on its opinion in the presentation of financial statements, because it is very influential in the decision making. Therefore, for users of financial statements, it is important to look at the quality of the public accounting (Susiana and Herawaty, 2007). Jama' an (2008) shows that the quality of the public accounting firm affects the integrity of financial statements.

Previous studies seem to support for the role of corporate governance mechanism to reduce the level of earnings management. For example, Burhee (1998) shows that institutional ownership affects the integrity of financial statements. Lin et al. (2006) demonstrate that managerial ownership affects the integrity of financial statements. Jama'an (2008) shows that independent directors and audit committees affect the integrity of financial statements.

This study aims to demonstrate empirically whether the independency moderates the influence of corporate governance mechanism and the quality of public accounting firms on the integrity of financial statements. Corporate governance is proxied by four mechanisms, namely, institutional ownership, managerial ownership, independent commissioners, and audit committee. Using a sample of 138 financial reports of companies listed on Indonesian Stock Exchange, the study finds that independency has a full moderating role in the relationship between institutional ownership, independent commissioners and quality of public accounting firm in the integrity of financial statements.

\section{Literature review}

1.1 Integrity of financial statement. Integrity means the quality, nature, or circumstances that indicate a unified whole having the potential and ability that include dignity and honesty. Statement of Financial Accounting Standards No. 2 (FASB, 1974) explains that the integrity of financial reporting information is information that depends on the financial statements being presented fairly, honestly, and not bias. The resulted information will be free of manipulation and so will not mislead users of financial statements. The financial statements will be regarded as having high integrity if they could meet the reliability and quality requirements in accordance with generally acceptable accounting principles.

2.2 Corporate Governance Mechanism and Earnings Management. There are some mechanisms for corporate governance. These include institutional ownership, managerial ownership, independent commissioners, and audit committee. The following is the description of each of these mechanisms and its relation to earnings management.

Institutional ownership is the sum of shares owned by institutions (insurance companies, banks, investment companies, asset management and other institutions) both inside and outside the country (Susiana and Herawaty, 2007). Institutional ownership encourages the emergence of a more optimal monitoring of the firms' performance. Through effective monitoring process, institutional investors are able to monitor the management so as to reduce the extent of earnings management.

Managerial ownership shows how much the managers own the shares. Once a manager owns the company's shares, she is also regarded as the shareholder of the company. The presence of owner manager shall be able to reduce the managers' intention to manage reporting earnings, as the impact of such action would affect her position, as well as her wealth. Managerial ownership is one of the mechanisms used to reduce the managers to perform activities that are not in the best interest of the majority owners of the company. Managerial ownership is seen as a tool to reconcile the interests of managers with the owners of the company and becomes one of the efforts to reduce agency problems which will reduce the intention of performing earnings management.

Independent commissioners are commissioners who are external to the company and have no relationship with the company. Their presence as the representative of independent shareholders, usually minority shareholders, represents the interests of investors (Surya and Yustiavananda, 2006). The obligation that a public company must have independent commissioners was based on the Regulation Number IA on Registration of Shares and Securities, a decision of the director of PT. Jakarta Stock Exchange Kep-305/BEJ/07-2004 dated 19 July, 2004. Company intended to list its shares on the main board should meet the requirements of having independent commissioners of at least $30 \%$ (thirty percent) from the total number of commissioners.

The audit committee is responsible for financial reporting and disclosure process (Tunggal, 2016). Rule Number IX.I.5 annex the Chairman of Bapepam Number: Kep-643 / BL / 2012 on the Establishment and Implementation Guidance of the Audit Committee explained that the audit committee consists of at least three (3) members from the independent commissioners and parties outside the issuer or public company and the audit committee is chaired by an independent commissioner. For proper discharge of duties, all members of the committee 
should be financially literate and have understanding of the industry where the company operates, and at least one member should have financial expertise and professional qualification of the recognized professional accounting bodies. When the audit committee carries out their responsibilities properly, the result is definitely the credible financial statements which is the basis for good corporate governance, and corporate failures will be avoided (Okpala, 2012)

Public accounting firm is a provision of various services by the public accounting profession for the public with ethical principles, namely, integrity (Mulyadi, 2002). Professional responsibility and integrity must be met by each member of public accounting firms in order to improve and maintain public confidence. Integrity requires that an auditor has to be honest and forthright without sacrificing the recipient secret services and the public trust for personal gains. The submission of financial reports shall be conducted by the company with the opinion of the independent public accountant.

Many Indonesian accounting firms have an affiliation with the Big 4 accounting firms for audit services. Public companies have option to use local accounting firm or accounting firms affiliated with one of the Big four accounting firms. Given this preference, the company may only have one or two real choices for the auditor of record under any mandatory rotation system given the importance of, industry expertise and the Sarbanes-Oxley Act's auditor independence requirements. However, over the time, a mandatory audit firm rotation requirement may result in more firms transitioning into additional industry sectors, if the market for such audits has sufficient profit margins. The Sarbanes-Oxley Act contains significant reforms aimed at enhancing auditor independence (e.g., additional partner rotation requirements and restrictions on providing non-audit or consulting services) and audit quality (e.g., establishing the PCAOB and management and auditor reporting on internal controls over financial reporting) that are also intended to achieve the same type of benefits as mandatory audit firm rotation (GAO Highlights, 2003). Previous studies usually use dummy variable to differentiate between prestigious and less prestigious accounting firms.

In 2001, Public Accountants Professional Standards PSA No. 04 section 220 paragraph 2 explained that independence means not easily influenced, because she was carrying out work in the public interest (differentiated in terms of practice as internal auditor). Thus, she was not justified in favor of the interests of anyone, because, if not, she would lose the impartiality that is the most important to defend freedom of opinion.

The independence within the scope of corporate governance In relation to the current institutional ownership and possession of managerial supervision and presentation of financial statements of integrity, when assessing the company's

performance, independent directors and the audit committee should interact with the internal audit function.

An ideal plan is needed to strengthen the independence of the audit function to report directly or indirectly to the audit committee (Tunggal, 2016).

According to Abu Bakar (2005), there are six factors that affect the independence of public accountants, one of them is any services other than audit conducted by the auditor for the client. Very often, client ask public accounting firms management to provide other services in addition to audit services. The provision of services other than audit services raises a fundamental question whether such public accountant has been trying to maintain independence.

\section{Hypotheses development}

Control measures undertaken by institutional investors will reduce the opportunistic behavior; selfishness of managers making it has to focus on improving the company's performance. According to Rustiarini (2010), a large proportion of institutional ownership may affect the value of the company which is realized with the creation of an effective supervision so that the financial statements are made which have high integrity. This argument leads to the following hypothesis.

H1: Independency moderates the influence of institutional ownership on the integrity of financial reports.

The existence of managerial ownership in a company can become an effective effort to reduce the manager agency problems and align the interests of managers and shareholders. This is in line with Jensen and Meckling (1976) who state that the number of managerial ownership may reduce the conflicts of interest and the agency problems. The manager who owns shares in the company will feel that the company is owned by her. That is why she would think that the financial statements must not be separated from high integrity. This argument leads to the following hypothesis.

$\mathrm{H} 2$ : Independency moderates the influence of managerial ownership on the integrity of financial reports. 
The presence of independent commissioners in a company can balance decision-making process of the company, especially in the context of the protection of minority shareholders and other parties concerned. This suggests that the presence of independent commissioners in a company can affect the integrity of the financial statements produced by the management. Susiana and Herawaty (2007) state that if a company has an independent commissioner, the financial statements presented by management tend to have higher integrity, because there are governing bodies that monitor and protect the rights of parties outside the company's management. This argument leads to the following hypothesis.

$\mathrm{H}_{3}$ : Independency moderates the influence of independent commissioners on the integrity of financial reports.

The audit committee serves to provide views on matters related to financial policies, accounting and internal control. The audit committee will ensure transparency, disclosure of financial statements, fairness to all stakeholders and disclosure of all information that is made by the management that will have an impact on the transparency of financial statements. At the same time, it can increase the integrity of the financial statements. This argument leads to the following hypothesis.

$\mathrm{H}_{4}$ : Independency moderates the influence ofthe audit committee on the integrity of financial reports.

According to Lenox (2000) and Susiana and Herawaty (2007), the reputation theory predicts a positive relationship between the size of the public accounting firm and audit quality. The services of the Big Four accounting firm are associated with more accurate audit quality than non accounting firm. It has been argued that public accounting firm affiliated with the Big Four has a greater level of independence and good reputation in performing audits of the clients'financial reports. This argument leads to the following hypothesis.

$\mathrm{H}_{5}$ : Independency moderates the influence of the quality of audit service on the integrity of financial reports.

\section{Methodology and model}

3.1. Population and sample. The population of this study are 460 companies listed on the Indonesian Stock Exchange in 2014 and there are 138 companies met the selection criteria and finally used as the sample firms. Table 1 details the process on the selection of the sample.
Table 1. Samples selection process

\begin{tabular}{|l|l|c|}
\hline \multicolumn{1}{|c|}{ No. } & \multicolumn{1}{|c|}{ Description } & Total \\
\hline 1. & $\begin{array}{l}\text { Companies listed on the Stock Exchange in } \\
2014\end{array}$ & 460 \\
\hline 2. & $\begin{array}{l}\text { Companies in the financial and investment } \\
\text { services sectors }\end{array}$ & $(76)$ \\
\hline 3. & $\begin{array}{l}\text { Companies with total net assets below IDR.1 } \\
\text { trillion }\end{array}$ & $(206)$ \\
\hline 4. & Companies with negative earnings & $(24)$ \\
\hline 5. & Companies with negative net worth & $(16)$ \\
\hline \multicolumn{2}{|l|}{ Total samples } & 138 \\
\hline
\end{tabular}

3.2. Measurement of variables. A. Integrity of financial statement.

Disclosure of integrity of the financial statements as the dependent variable is measured as follows (Penmanand Zhang, 2002:243).

$C_{i t}=\left(I N V_{i t}^{r e s}+R D_{i t}^{r e s}+A D V_{i t}^{r e s}\right) / N O A_{i t}$

where:

$\mathrm{C}_{i, t} \quad$ Company ConservatismIndex $i$ in year $t$.

$\mathrm{INV}^{\text {res }}{ }_{i, t} \quad$ Inventory reserve equals the LIFO reserve reported in the financial statements footnotes of the company $i$ in year $t$.

$\mathrm{RD}^{\text {res }}{ }_{i, t} \mathrm{R} \& \mathrm{D}$ reserve is calculated as estimated amortization R\&D assets in the financial statements of the company $i$ in year $t$.

$\mathrm{ADV}_{\mathrm{i}, \mathrm{t}}^{\mathrm{res}} \quad$ Advertising reserve is the estimated brand assets created by advertising expenditure of the company $i$ in year $t$.

$\mathrm{NOA}_{i, t}$ Net operating assets, as measured by the formula of net financial liabilities (total debt + total equity + total dividends $)-($ cash + total investment $)$ of firm $i$ in year $t$.

Institutional ownership is measured as the percentage of shares owned by the institution of the entire outstanding shares (Jama'an, 2008).

Managerial ownership is measured as the percentage of ownership of shares owned by management and actively participates in corporate decision over the company's outstanding shares (Susiana and Herawaty, 2007).

Independent commissioners is measured as the percentage of the total number of independent commissioners over total number of commissioners (Susiana and Herawaty, 2007).

The audit committee is calculated using the number of audit committees engaged in the company (Jama'an, 2008).

Quality of public accounting firm is measured using dummy variable. If the company is audited by public accounting firm affiliated with the Big Four 
Accounting Firm, it is given a value of 1 , and 0 otherwise (Susiana and Herawaty, 2007).

The independency is measured by calculating the length of the relationship of public accounting firmwith the client company (Jackson et al., 2008; Al-Thuneibat et al., 2011).

3.4 Moderated regression analysis. The regression model used to test the proposed hypotheses is as follows:

$Y=\alpha+\beta_{1} X_{1} X_{6}+\beta_{2} X_{2} X_{6}+\beta_{3} X_{3} X_{6}+\beta_{4} X_{4} X_{6}+$ $+\beta_{5} X_{5} X_{6}+\varepsilon$

where:

$\mathrm{X}_{1} \mathrm{X}_{6}$ : interaction between institutional ownership and independency

$\mathrm{X}_{2} \mathrm{X}_{6}$ : interaction between managerial ownership and independency

$\mathrm{X}_{3} \mathrm{X}_{6}$ : interaction between independent commissioners and independency

$\mathrm{X}_{4} \mathrm{X}_{6}$ : interaction between the audit committee and independency

$\mathrm{X}_{5} \mathrm{X}_{6}$ : interaction between quality of public accounting firm and independency

$\varepsilon \quad$ : error

\section{Results and discussion}

4.1. Descriptive Analysis. The descriptive statistics of variables examined in this study is presented in Table 2 .

Table 2. Descriptive statistics of variables $\mathrm{N}=138$

\begin{tabular}{|l|c|c|c|c|}
\hline \multicolumn{1}{|c|}{ Variable } & Minimum & Maximum & Mean & $\begin{array}{c}\text { Standard } \\
\text { Dev. }\end{array}$ \\
\hline $\begin{array}{l}\text { Integrity financial } \\
\text { statements }\end{array}$ & 0.00 & 3.43 & 0.239 & 0.421 \\
\hline $\begin{array}{l}\text { Institutional } \\
\text { ownership (\%) }\end{array}$ & 7.93 & 98.24 & 63.569 & 21.089 \\
\hline $\begin{array}{l}\text { Managerial } \\
\text { ownership (\%) }\end{array}$ & 0.00 & 65.00 & 2.621 & 9.344 \\
\hline $\begin{array}{l}\text { Independent } \\
\text { commissioner (\%) }\end{array}$ & 0.00 & 80.00 & 35.579 & 16.868 \\
\hline The audit committee & 2.00 & 6.00 & 3.203 & 0.568 \\
\hline $\begin{array}{l}\text { Quality of public } \\
\text { accounting firm }\end{array}$ & 0.00 & 1.00 & 0.572 & 0.496 \\
\hline The independence & 1.00 & 7.00 & 3.609 & 1.416 \\
\hline
\end{tabular}

Table 2 shows that the integrity of financial statements has an average of 0.2397 with a standard deviation of 0.42122 . These results indicate that the average sample companies have low conservatism.

Institutional ownership variable has an average of 63.56 with a standard deviation of 21.08. The managerial ownership variable has an average of 2.62 indicating that the shares owned by manager is relatively low. Independent commissioner has an average of 35.57 with a standard deviation of 16.86 . This figure suggests that a third of the commissioners are the independent commissioners.
Audit committee has an average of 3.20 with a standard deviation of 0.56 . A total of 79 companies were audited by accounting firms affiliated with one of the four accounting firms. Independency has an average value of 3.60 with a standard deviation of 1.41. There are ten companies which have the highest index of 7.0.

4.2. Results of multiple regression analysis. After the regression model has been declared feasible, the hypotheses were tested. Results of the regression analysis are shown in Table 3.

Table 3. Results of regression analysis

\begin{tabular}{|l|c|c|c|c|}
\hline \multicolumn{1}{|c|}{ Variable } & $\begin{array}{c}\text { Standardized } \\
\text { coefficients }\end{array}$ & Standard error & $\mathrm{t}$-stat & $\begin{array}{c}\text { Sig. } \\
\text { level }\end{array}$ \\
\hline (Constant) & & 0.757 & -5.875 & 0.000 \\
\hline $\begin{array}{l}\text { Institutional } \\
\text { ownership }\end{array}$ & 0.443 & 0.005 & 5.482 & 0.000 \\
\hline $\begin{array}{l}\text { Managerial } \\
\text { ownership }\end{array}$ & 0.116 & 0.011 & 1.465 & 0.145 \\
\hline $\begin{array}{l}\text { Independent } \\
\text { commissioner }\end{array}$ & 0.177 & 0.006 & 2.392 & 0.018 \\
\hline $\begin{array}{l}\text { The audit } \\
\text { committee }\end{array}$ & 0.069 & 0.170 & 0.923 & 0.358 \\
\hline Quality of KAP & 0.084 & 0.195 & 1,116 & 0.267 \\
\hline $\begin{array}{l}\text { The } \\
\text { independence }\end{array}$ & -0.170 & 0.069 & -0.170 & 0.027 \\
\hline
\end{tabular}

Institutional ownership moderated by independency affects the integrity of financial statements. Institutional ownership will improve the integrity of the financial statements, because they are not affected from the outside and within the company so that the monitoring process would be more effective. Surveillance measures by institutional investors will reduce the opportunistic behavior of manager that would reduce the intention to manage accounting performance. They may encourage managers to focus on her attention to improve the integrity of the financial statements. The finding of this study supports previous results of Jama'an (2008), Burhee (1998), and Cornett et al. (2006).

Managerial ownership moderated by independency does not affect the integrity of financial statements. The percentage of managerial ownership in most of Indonesian public firms is relatively small resulting in less independence in the decision making thereby increasing in the financial edit to; statements to be more conservative. Small percentage of managerial ownership would lessen their role in making decisions about the company's management and span with the agency problem that will make financial statement to be more conservative. This finding is in line withthe reports of previous studies (Cornett et al., 2006; Burhee, 1998; Hermalin and Welsbech, 1991).

Independent commissioner moderated by independency significantly affects the integrity of 
financial statements. Higher attitude of independence would make an independent commissioner to have more independent in assessing the company's performance and monitoring with no partiality to anyone. The proportion of independent members in the board of directors can be regarded as indicators of independence of the board of management. Independent commissioner shall be able to perform the functions of monitoring and can be a mediator in any disputes within the company so that they can realize the integrity of the financial statements. The finding of this study advocates those of Jama'an (2008) and Cornett et al. (2006).

The audit committee moderated by independency does not affect the integrity of financial statements. The independence is difficult to apply within the scope of the audit committee due to the audit committee is still under the influence of the commissioners, while independence requires to be impartial and without prompting from anyone. The existence of an audit committee is not a guarantee of high performance of the company, because many members will have difficulty in carrying out their respective roles and the fact that the audit committee is still under the influence of commissioners. The result reported here is in support of Jackson et al. (2008), Al-Thuneibat et al. (2011) and Hermalin and Welsbach (1991).

The quality of public accounting firms moderated by the independency affects the integrity of financial statements. The independency is needed in the public accounting firm for public accountants, as the company will always be dealing with the clients. The independence of public accountants is required to carry out their work in the public interest and does not show partiality to anyone. Public accounting firm either affiliated or not- affiliated with the big four accounting firms seems to have little intention to keep reputation. The finding of this study is in support those of Cornett et al. (2006) and Lin et al. (2006).

\section{Conclusion}

This study examines the moderating role of independency on the relationship between corporate governance mechanism and institutional ownership, managerial ownership, independent commissioners, audit committee and the quality of public accounting firm on the integrity of financial statements. A total of 138 companies listed on the Indonesian Stock Exchange during in 2014 were examined. Results indicate that independency has a full moderating role on the relationship between institutional ownership, independent commissioners and quality of public accounting firm on the integrity of financial statements. Independency has no moderating role in the relationship between managerial ownership and audit committee on the integrity of financial statements.. The attitude of independence must be presented by the organs of corporate governance and public accounting firms when carrying out their duties in order to reflect free from any influence and being honest to creditors, employers, and others who put trust in the financial statements. Loss of independence stance will lead to decline in the integrity of financial reports produced, so there was some doubt to be used as a basis for decision making.

Given the findings reported here, future study may extent the sample size and the period to look at the possibility of the effect of longer tenure of partnership on the extent of financial report integrity issues. Future study may also focus on differentiating the companies to be examined as we may argue that industrial difference may bring about different intention and level of moderating effect of various measures of corporate governance on independency of accounting firm.

\section{Reference}

1. Abu Bakar, N.B., Abdul Rahman, A.R., and Abdul Rashid, H.M. (2005). Factors Influencing Auditor Independence: Malaysian Loan Officers' Perceptions. Managerial Auditing Journal, Vol. 20., No.8, pp. 804-822.

2. Al-Thuneibat, A.A., Ibrahim Al Issa, R.T. and Ata Baker, R.A. (2011). Do Audit Tenure and Firm Size Contribute to Audit quality? Managerial Auditing Journal Vol. 26, No. 4, pp. 317-334.

3. Burhee, B.J. (1998). Institutional Investor, Long Term Investment and earnings Announcement, the Accountung Review, Vol. 73, No. 3, pp. 305-333.

4. Cornett, M.M., A.J. Marcus, A. Saunders and H. Tehranian.(2006). Earnings Management, Corporate Governance, and True Financial Performance, Working Paper, Boston College. Financial Accounting Standards Board. (FASB). (1974). Statement of Financial Accounting Standars No. 2. Accounting for Research and Development Costs.

5. GAO Highlights. (2003). Public Accounting Firms: Required Study on the Potensial Effects of Mandatory Audit Firm Rotation. Report to the Senate Committee on Banking, Housing, and Urban Affairs and the House Committee on Financial Services.

6. Hermalin, B. and Welsbasch, M.S. (1991). The Effect of Board Composition and Direct Incentives of Firm Performance, Financial Management, Vol. 20, pp. 101-112. 
7. Indonesia Accounting Association. (2001). Professional Standards of Public Accountant as of January 2001, Part 220 PSA No. 04 paragraph 02, Salemba Empat: Jakarta.

8. Jackson, A. B., Moldrich, M. and P. Roebuck. (2008). Mandatory Audit Firm Rotation and Audit Quality. Managerial Auditing Journal, Vol. 23, No. 5 pp. 420-437.

9. Jama'an. (2008). The Effect of Corporate Governance mechanism and the Quality of Public Accounting Firms in the Integrity of Financial Statements, Unpublished Thesis Diponegoro University, Semarang. Indonesia.

10. Jensen, M. and Meckling, W. (1976). Theory of the Firm: Managerial Behaviour, Agency Cost, and Ownership Structure, Journal of Finance Economics, Vol. 3, pp. 305-360.

11. Kieso, E.D., Weygandt, J.J. and Warfield, T.D. (2007). Intermediate Accounting. The 12 ${ }^{\text {th }}$ Edition, Vol. 1, Erlangga: Jakarta.

12. Lin, J.W., Li, J.F. and Yang, J.S. (2006). The Effect of Audit Committee Performance on Earning Quality, Managerial Auditing Journal, Vol. 21, No.9 pp. 921-933.

13. Mayangsari, S. (2003). Analizes The Effect of Independency, Quality Audit and Corporate Governance Mechanisms on The Integrity of Financial Statements, Accounting National Symposium VI, Surabaya. Indonesia.

14. Ministers of State Decision BUMN Number: Per-01/MBU/2011 On the Application of Good Corporate Governance.

15. Mulyadi. (2002). Auditing. Salemba Empat: Jakarta.

16. Norwani, N.M., Mohamad, Z.Z. and Chek, I.T. (2011). Corporate Governance Failure and Its Impact on Financial Reporting Within Selected Companies, International Journal of Business and Social Science, Vol. 2, No. 21, pp. 205-213.

17. Okpala, K.E. (2012). Audit Committee and Integrity of Financial Statements: A Preventive Mechanism for Corporate Failure, Australian Journal of Business and Management Research, Vol. 8, pp. 32-40.

18. Penman, S.H., and Zhang, X.J. (2002). Accounting Conservatism and the Quality of Earnings and Stock Returns.The Accounting Review, Vol. 77. No. 2, pp. 237-264.

19. Rustiarini, N. W. (2010).The Effect of Corporate Governance on the Relationship of Corporate Social Responsibility and the Value of the Company, Accounting National Symposium XIII Purwokerto, Indonesia.

20. Surya, I. and Yustiavanda, I. (2006). Implementation on Good Corporate Governance: Waive any Privilege for Shake of Business Continuity. Lembaga Kajian Pasar Modal dan Keuangan Fakultas Hukum Universitas Indonesia, Jakarta.

21. Susiana dan Herawaty, A. (2007).Analysis of the Influence of Independency, The Mechanism of Corporate Governance, Audit Quality on the Integrity of Financial Statement. National Accounting Symposium X., Makassar, Indonesia.

22. The World Bank. (2005). Corporate Governance Country Assessment: Malaysia. The World Bank.

23. Tunggal, A.W. (2016). The Fundamental Basis of the Auditt. Harvarindo: Jakarta. www.bpk.go.id. Accessed April $5,2016$. 